\title{
TENDENCIES IN CONTEMPORARY ARCHITECTURAL DESIGN OF ECOLOGICAL HOTELS IN POLAND - A STUDY OF NATURAL SOLUTIONS
}

\author{
E. TROCKA-LESZCZYŃSKA \& J. JABLONSKA \\ Faculty of Architecture, Wroclaw University of Technology, Poland
}

\begin{abstract}
Contemporary architectural design of ecological buildings is characterized by two different trends. The first trend is the search for traditional solutions that could be modified to address contemporary problems in proper functioning of buildings. The second is focused on recent technological developments in the field of energy optimization and renewable resources. Most researchers in this area focus on single-family houses, and there are very few thorough studies on hotels. The main objective of this paper is to find out which of the aforementioned trends is optimal for both new and renovated Polish hotels. The solutions discussed in this paper are focused on the specifics of Polish climate. This article also examines the traditional and contemporary solutions in Polish hotels and compares them with international best practices. As indicated in the title, the primary focus of this paper is on simple, natural solutions. These solutions have been neglected by contemporary Polish architects because they take longer to build and have a low rate of return on investment. Moreover, with the growing fascination with technological novelties, investors have become reluctant to use traditional construction techniques. Keywords: ecological hotel, ecological solutions, environmental-friendly policies.
\end{abstract}

\section{INTRODUCTION}

At the beginning of the 20th century, humanity became fascinated with technology, which fuelled the dynamic development of IT solutions and led to the computerization of each domain of human life at the turn of the 21 st century. Along this process, constant urbanization has led to pollution, noise and enormous energy usage. This is especially evident in the building industry, which consumes up to $40 \%$ of overall energy used [1] in the world. It is not surprising that these numbers sparked ecological movements, which the hotel industry has also started following by implementing architectural solutions designed to limit harmful effects on the environment. Over the last decade in Poland, there has also been an increase in the popularity of ecological spas, agritourism and nature-friendly hotels.

Two different trends towards designing ecological hotels have emerged in contemporary architecture. The first trend is the use of recent technological advances to optimize energy consumption and harness renewable resources (which will be referred to in this article as 'technological method'). The second trend focuses on adapting traditional solutions to contemporary needs (which will be referred to in this article as 'natural method'). The main objective of this paper is to compare these two opposite trends to determine which one is the most suitable for both new and renovated Polish hotels. Moreover, the article investigates the possibility of combining both trends so as to produce the optimal solution.

\section{RESEARCH AND METHODS}

This article is the result of a preliminary study of about 50 Polish hotels, aimed at identifying those that adopt environmental-friendly practices, which concluded that such solutions are unpopular. Many of the examined hotels usually adopt only small-scale measures, such as waste sorting or towel re-use programmes, which, from the architectural point of view, are insignificant in terms of environmental protection. According to studies carried out in 2010 by Network Starwood Hotels \& Resorts [2], 69\% of Polish travellers choose their places of stay based on pro-environmental policies.

(C) 2015 WIT Press, www.witpress.com

ISSN: 1755-7437 (paper format), ISSN: 1755-7445 (online), http://journals.witpress.com

DOI: $10.2495 / \mathrm{DNE}-\mathrm{V} 10-\mathrm{N} 2-114-126$ 
These results imply that it is in the interest of hotel owners to turn more attention to ecological solutions. However, there is insufficient research exploring the needs and requirements of this industry. There are so many new technologies that it is hard to predict which one will be useful for hotels in the long term. Because there is little experience and very few good practical examples in this field, owners are cautious about making risky investments. This fact justifies the need for further studies in this area. It is important to emphasize that this article only covers architectural solutions.

The primary aim of this paper is to compare the two aforementioned methods of contemporary ecological design, i.e. the natural method and the technological method, to find the one that is optimal for Poland, whose climate is very specific and varies with altitude. The study employs various scientific methods, such as case, literature and field studies, analysis of best practices, graphical synthesis and synthesis. The case studies included chosen architectural objects (single- and multifamily houses, offices, commercial buildings and hotels) erected between 2002 and 2012 all over the world. Among the studied examples were both buildings with and without ecological solutions, and in the first group were those which adopted either natural or technological solutions. The last part of the study compared natural and technological solutions to achieve the goals of this article.

One of the most difficult tasks involved in the study of ecological aspects of contemporary architecture is defining what an environmental-friendly building is. Using only some small-scale ecological solutions, e.g. energy-saving light sources, or large-scale solutions such as renewable energy sources, seems to be a misunderstanding of the main idea. It is crucial to understand that in both these cases, the costs associated with producing energy needed to implement such technologies may outweigh the benefits that they offer. Moreover, even if considerable savings are made, there is still the problem of demolition and waste management after these resources become obsolete. It is very important not to overlook any of the aforementioned aspects in the analysis so as not to narrow the scope of considerations.

\section{DISCUSSION}

In the previous paper on the same subject, the following definition was formulated [3]: 'ecological hotel is understood as a one with solutions aimed at limiting its harmful influence on the natural environment or human health, and one which harmonizes with its (urban or rural) surroundings'. This definition was connected with the following interpretation by Gwóźdź [4]: 'ecology is a science about the structure and functioning of nature with research focusing on interactions between organisms and their environment and also between organisms themselves.' Both of these rather broad statements do not propose any method of providing ecological solutions for buildings. The definition would be much more useful if it incorporated these very important aspects of natural or technological solutions for hotel buildings. Zielonko-Jung and Marchwiński [5] define traditional architecture as one that is connected with nature by responding to the climate and culture, restricting the scale of the buildings and using local materials. Such solutions usually come at the cost of lower living standards for users. The paper recalls both natural solutions, such as vernacular, low-tech and green architecture, as well as those based on advanced technologies, such as high-tech and eco-tech, which evolved from the former and aim at creating environment-friendly buildings.

\subsection{Two directions}

As far as natural solutions are concerned, Trocka-Leszczyńska [6], Zaniewska and Barek [7] turn their attention to traditional Polish architecture. They focus on existing Polish country houses that were designed in accordance with climate requirements in terms of form, function and technology. Their roof shapes, walls, doors and the placement of windows, the choice of building materials and 
types of structures were based on analyses of wind, rainfall and snow, as well as the locally available resources. Architectural knowledge based on experience and on-site experiments, but not supported by scientific research, was sufficient to construct single-family homes. With the growing population came the need to erect more complicated multi-storey buildings, which could not be satisfied by natural solutions. The accompanying technological progress seemed like an easy remedy to these new problems and dispensed with the need to connect with nature and protect the environment. Additionally, the introduction of aesthetics trends in architecture, such as modernism and postmodernism, deprived designs of context requirements [8].

In Poland, this process was further exacerbated by the political conditions after the war. The government not only promoted uniformity, which resulted in the lack of spatial identity in the city and country, but also turned a blind eye to the use of poor quality building materials and lack of maintenance. This situation continued until the 1990s. The last 15 years have witnessed a gradual revival of some natural solutions, such as the use of local building materials. The simplicity of technological processes used to produce these materials helps to decrease energy significantly to reduce waste and pollution. These building materials include sun-dried brick, stone, concrete, straw, wood and glass. Some of them, e.g. sun-dried brick or stone, are ready to use after simple forming and cutting, while others, e.g. wood or straw, require additional fire-safety protection [9].

Natural solutions are based on the relations between a building and its surroundings. Hence, to some extent, the inner environment is always dependent upon external parameters. If the air outside is 'too dry', it will easily penetrate into the building before users manage to humidify it, e.g. by hanging wet pieces of cloth near air inlets. Another example of this dependency is that natural ventilation systems fail in bad weather, e.g. during a storm. Thus, a question arises whether to implement natural solutions in hotels at the cost of comfort of guests. The technological approach usually isolates a building from its environment and creates inner conditions that are more or less the same throughout the year. All microclimate parameters, such as air temperature, humidity, velocity of air flow, amount of natural light, are controlled by special electronic systems, which operate 'outside' the interiors. This guarantees the same level of comfort for hotel guests regardless of external weather conditions (Fig. 1).

Among eco-tech solutions connected with architecture, the following should be mentioned: solar panels, recuperators, energy saving light bulbs, BMCS (Building Monitoring and Control System), heat pumps, low power consumption air-conditioners, smart shading systems, smart materials (i.e. those which respond to changes in certain external parameters [5]), heating with the use of ecological solid fuels (e.g. industrial wood waste), combustion of biomass, hydrogen or photovoltaic cells, wind or water turbines and other ideas, such as dusk sensors for exteriors, aerators on water outlets, or energy-saving electronic utilities and appliances. The second group of low-tech solutions includes, e.g. passive energy heating and accumulation, traditional shading systems, sun-chimneys, wind towers, low-tech materials, low-waste production, proper construction of building compartments, elimination of thermal bridges and other less important devices, such as using showers instead of bathtubs or twin-tank flushing systems.

Regardless of which system is chosen in a hotel, some other problems always emerge. The proper functioning of every solution is dependent upon individual users. For example, if an BMCS system, which control the heating and ventilation of each room by means of an HVAC units (heating, ventilation and air conditioning) is to function properly, the whole building must be air-tight. However, some guests in need of fresh air, instead of filtered air, might open a window, which certainly would affect the original design parameters. Prohibiting a user from regulating the flow of fresh air via external openings may decrease the popularity of a given hotel. Numerous facilities have already introduced such policies, and guests in many hotels often complain about the air-conditioning. Sim- 


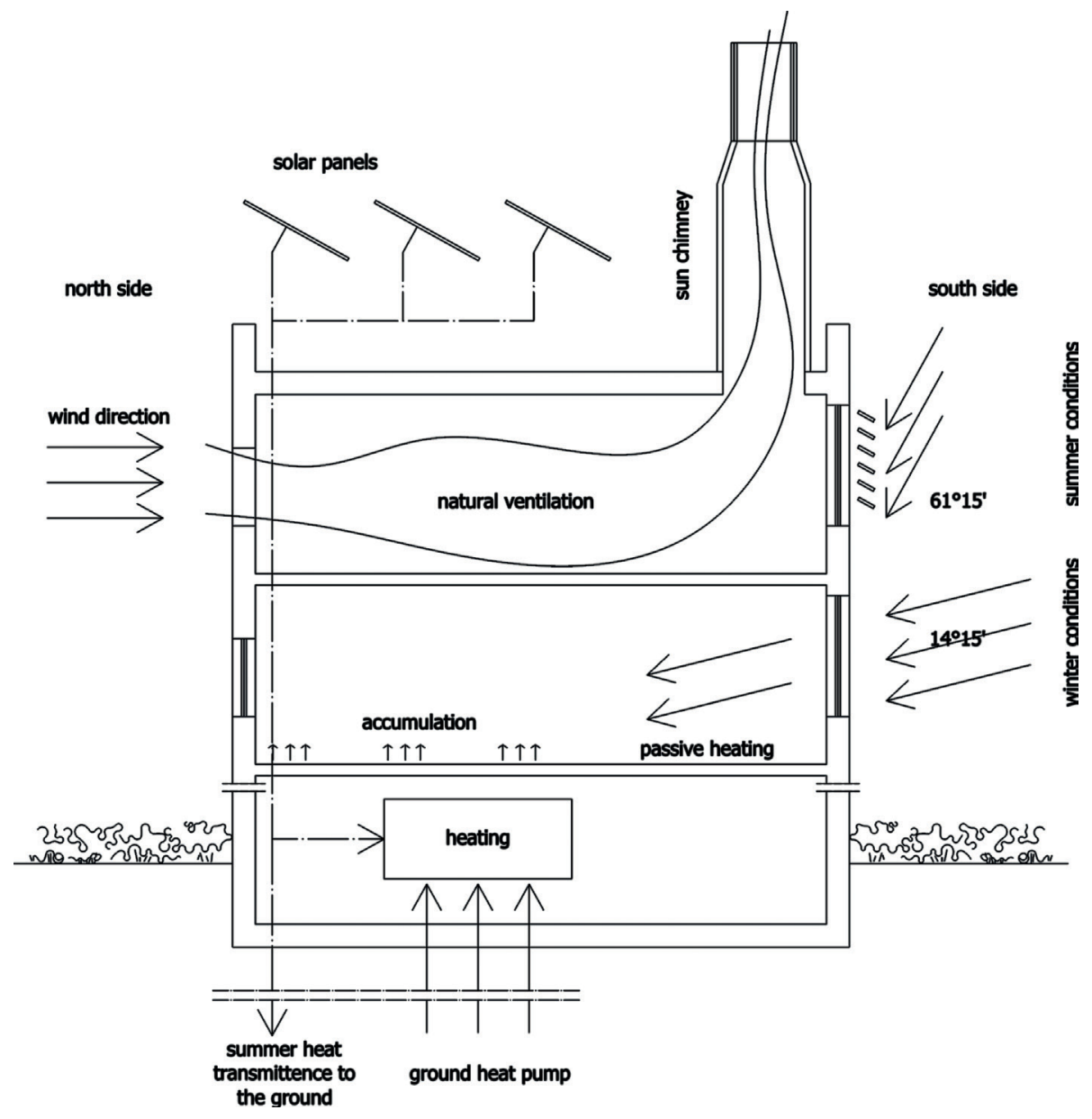

Figure 1: An example of an open, natural cooling and heating system.

ilar problems exist in the case of natural solutions. In a hotel building with cross ventilation, the whole system could be disrupted by users who close certain air-inlets in rooms (Fig. 2).

Another aspect of both natural and technical solutions is their influence on the architecture and aesthetics of the building. There is strong tendency to blend technological solutions with architectural elements, e.g. sunscreens of the California Academy of Science by architect Renzo Piano or, in the case of natural solutions, the dome with a sun-chimney on Reichstag designed by Sir Norman Foster. These problems shall be addressed in the following sections of this paper.

\subsection{Physical conditions}

According to the Polish Institute of Meteorology and Water Management (Pol. Instytut Meteorologii i Gospodarki Wodnej - IMGW) [10], day temperatures above $25^{\circ} \mathrm{C}$ will be experienced by humans as too high, whereas temperatures over $30^{\circ} \mathrm{C}$ are defined as hot. Also temperatures lower than $10^{\circ} \mathrm{C}$ are considered disadvantageous and, when combined with strong wind, they can be hazardous to health, even for people dressed accordingly to weather conditions. It should be emphasized that even 


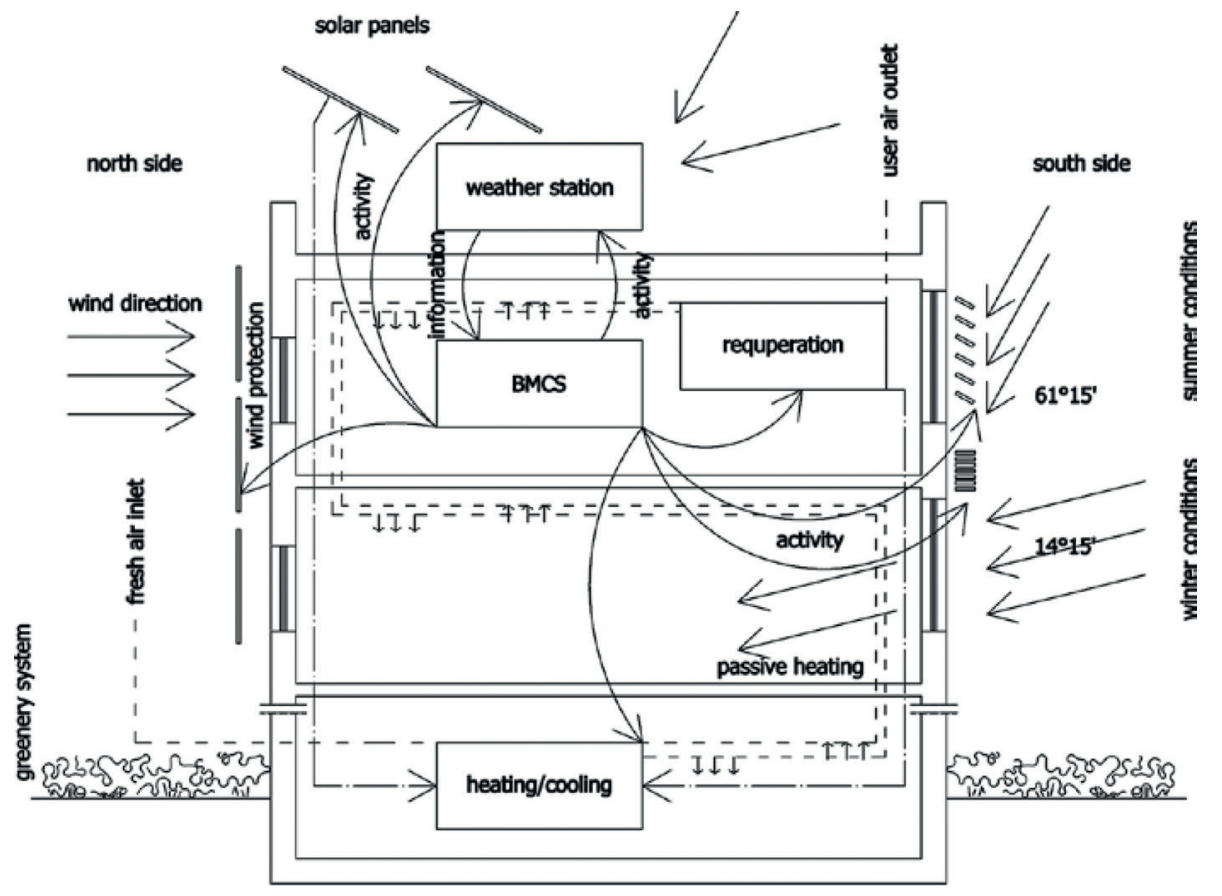

Figure 2: An example of a closed, eco-tech cooling and heating system.

indoors people are subject to potential health risks caused by the fast and directional wind flows called 'drafts', which take the form of a rapid uncontrolled air movement and may lower the temperature very quickly. On the other hand, a mild air breeze is considered to be refreshing and cooling on hot summer days, but, to achieve this effect, the airflow should not be too slow, i.e. at least 0.2 $\mathrm{m} / \mathrm{s}$ according to IMGW [10].

Another important factor is the behaviour of human organisms, which influences all the technological aspects of cooling and heating in both natural and technological processes. As Krause [11] suggests, organisms create about $80 \%$ of their heat through metabolism and if they cannot release it to the external environment within $15 \mathrm{~min}$, the heat may become hazardous to their health. The two most relevant methods of distributing heat to the exterior are the dry process of convection and the wet process of perspiration. The former is based on the movement of air particles from the human skin upwards when heated and downwards when cooled. When still air touches the skin, the exchange of heat is possible through the process of conduction, whose value is minimal and reaches $0.023 \mathrm{~kJ} \times \mathrm{m}^{-1} \times \mathrm{s}^{-1} \times \mathrm{K}^{-1}$ [11]. The latter process - perspiration - is based on the cooling effect caused by evaporation of water from the skin. As opposed to convection, this is a unilateral process. Based on these considerations, it can be said that only convection can be applied as an architectural solution to cool down the human organism.

\section{DETAILED STUDIES}

\subsection{Air-conditioning/cooling and heating}

In Poland, ecological heating has become much more popular than it was, for instance 10 years ago, because it is easier to obtain (commercialization process), clean (people naturally tend to live in a 
clean environment rather than in a polluted one), increasingly cheaper to install and offers the possibility to obtain European Union funds for different solutions. Such systems are not more faulty or problematic in terms of maintenance than conventional ones and they are economical and functional. Owing to the aforementioned aspects, these types of systems are popular in Polish towns and villages. Natural cooling is much less effective, especially in large buildings designed to provide safety, comfort and even luxury. In a hotel, silent air conditioning is the investor's first choice even if it means that guests could suffer from skin and eye discomfort, allergies and even legionella poisoning (when air channels are poorly maintained). This is the reason why natural air-cooling solutions should be studied, especially in Poland where the summer climate is not as severe as in the said dry hot climates [6,12].

\subsubsection{Traditional chimney ventilation}

First, it is important to have a closer look at the problems connected with local solutions. A typical Polish natural ventilation system consists of gaps in the insulation of windows or mechanical ventilators, which run on the basis of the difference of air pressure between the interior and the exterior or the difference in air humidity [13]. In the past, it was possible to make other gaps in the building structure as part of the overall system; however, the current building regulations require that most of the buildings be air-tight [14]. The exhaust air in the natural system is ejected by ventilation chimneys due to buoyancy, i.e. the difference in indoor-to-outdoor air density. This solution is only effective as long as interiors are warm and the exterior is relatively cool, which occurs in early spring, autumn and winter. Given the need for summer cooling and the potential likelihood of failure, e.g. due to rainy weather, frequent wind direction changes and other anomalies, this solution is not recommended for hotels. It would be much more effective to use the so-called 'solar-chimneys', which, due to their height, are heated by solar energy in the upper part. To increase the thermal effect, the top of the construction may be glazed [5]. Considering the fact that this solution is very popular in Great Britain, where the annual irradiation averages between 900 and $1300 \mathrm{kWh} \mathrm{m}^{-2}$, 'solar-chimneys' may be recommended for Polish hotels, where the same parameter ranges on average from 1200 to 1300 $\mathrm{kWh} \mathrm{m}^{-2}$ per year [15]. The cited data are based on a map prepared for [15]: 'yearly sum of global irradiation incident on optimally-inclined south-orientated photovoltaic modules' [6].

\subsubsection{Wind towers}

A ventilation system consisting of wind towers, 'Bādgir' (Persian) and 'Malquaf' (Arabic), is known to have been used already in medieval times (some relics date back to around 2nd century BC [16]). Because these towers are used in very dry areas, they were usually associated with air humidification. These solutions are based on a reverse chimney effect, which directs airflow into a building using the pressure of the wind. Such towers were built in the form of high and broad chimneys on rectangular or polygonal plans, with air inlets located on the top part of the wall and facing the prevailing wind. Other popular solutions comprise two chimneys on opposite sides of the tower (inlet and outlet) or multiple chimneys, especially in locations where the wind blows from different directions. The air is additionally cooled by water in tanks on top of the tower or directly beneath it in the basement, where it is easily stored at low temperature. The air usually flows through a green court yard with a small water container or a fountain, where it is cooled again. After penetrating the entire building, the exhaust air is removed through another chimney or through additional channels in the same tower. When a reverse chimney effect is no longer active, exhaust air is removed by gaps in windows and doors, which function as emergency air outlets [5,16,17].

It is important to determine whether it is possible to promote such solutions in Poland. First, one cannot expect the wind to blow only in one direction in potential hotel locations. The direction of 
airflow often depends on the time of day, time of year, general weather conditions and the surrounding buildings. Secondly, water stored in the container could easily become breeding grounds for bacteria, which would require additional mechanism to keep the water clean. In dry and hot climates, the bacterial contamination is less likely to occur. However, there are several contemporary examples of solar-chimneys and wind towers, such as: the Reichstag dome, designed by Sir Norman Foster, which uses the 'downdraught evaporating cooling' Cucinella concept with 'micronisers' [5], a French school in Damascus, Syria by Ateliers Liona and Transsolar, where the concept of 'qanat' is used [18] or a tower 'Burj-Al-Taqa', which, by implementing the concept of a wind tower, uses only $40 \%$ of energy that would normally be required for a building of this size and form. Cooling by means of evaporation was also used, e.g. in Ken Yeang's private home [8], which is located in the warm Malaysian climate. A swimming pool located on the windward side of the structure helps to cool down the whole interior.

The Arabic solution can be successfully used in mountain regions of Poland where hotels are located on slopes. In this specific landscape, strong and highly directional winds blow both in winter and summer. If the location of a building on a hill takes into account the local wind measurements and parameters, the wind will create pressure on the tower. An additional advantage is that the lower parts of the building, which are contact with ground, will warm up. This effect will strengthen the air movement from cooler parts of the walls towards the warmer ones (Fig. 3).

It is worth mentioning that contemporary wind-based eco-tech solutions, such as small and large wind turbines, have been criticized for noise and vibration, which are dangerous to humans and animals. Additionally, they are harmful to birds and insects that can be killed or injured if they collide with turbine blades. Large fans may also be disadvantageous to the appearance of facades, roofs and whole buildings. Of course, contemporary wind turbines are used mostly for generating electricity not only for cooling. However, it is advisable to search for a simpler and more original application of airflow in the construction industry. Nowadays, electricity can be successfully acquired from renewable resources in a less harmful manner.

\subsubsection{Glen Murcutt works}

Solutions using natural ventilation, lighting, heating and materials are promoted by Glen Murcutt, an Australian architect whose works are worthy of our attention because they were distinguished with the Pritzker Prize in 2002. His main interest was in single-family houses, which, although much

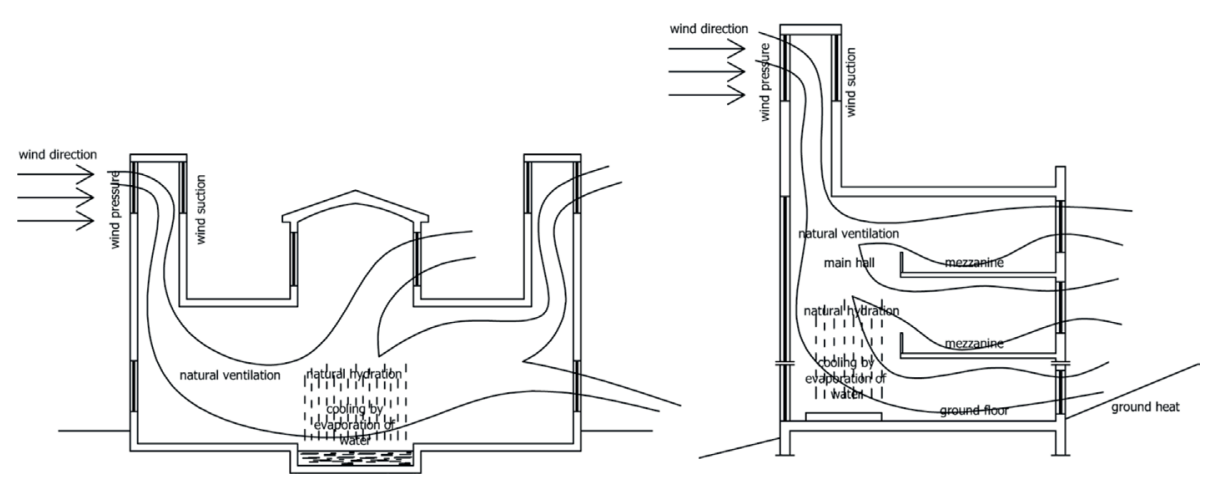

Figure 3: From left: general scheme of natural ventilation system with a wind tower, scheme for a multi-storey hotel with mezzanines and with a wind tower - a solution proposed for highlands. 
smaller than a hotel, can be compared with a single hotel unit in terms of size and volume. Most of Glen Murcutt's designs are built on a wide, horizontal plan, which enables simple, natural ventilation of the houses. The air enters through large panels on one side of the building and exits through small slots on the opposite side. Based on a study of various solutions, such as the 'Simpson-Lee House', 'Magney House' or 'Marika-Alderton House', it can be noticed that the air does not flow directly but is forced upwards, which helps to eliminate drafts. The upward air movement also helps to ventilate different parts of the interior. A simplification of the layout and reduction of the number access corners or structures also improve the hygienic aspects of this solution. This concept has been present throughout the history of single-family housing since antiquity but is worth analysing due to its high efficiency in the hot Australian climate [19-24].

One of the solutions that can be implemented in hotel design is a structure that allows natural airflow throughout the building. If large constructions could be composed of single 'Murcutt' units, each of them could be ventilated as described above. However, for this kind of segment-based design to function properly, it is necessary to take into account the direction of airflow through different modules. Such experiments and solutions have been tested on a number of multi-family houses with varied degrees of success. A good example of a cross-ventilation solution would be the residential 'Corte Verona' in Wroclaw designed by Lewicki-Łatak studio. This quarter city block has a classical corridor layout but the living modules are placed in a 'chessboard' pattern in the cross-section. Each of the residential 'boxes' was equipped with a corner-window. These openings and the free space created between the modules were the ones where fresh air entered into each apartment. This solution shows that it is possible to offer users a natural cooling system even if the building has a corridor-shaped plan, which is disadvantageous for natural ventilation, and, at the same time, is most effective for usable space to overall space ratio [25] (Fig. 4).

This system can be successfully used in large structures located in cities with open spaces both in flat and hilly terrain. The airflow can be stimulated by heating the south wall of a building and by cooling the shaded one by means of large openings to let air in, and small openings to let air out. It is important to remember that fast and direct airflow will cause drafts, which is why ventilation slots and gaps must have the possibility of being screened or closed. If there is no open space and the hotel is surrounded by a dense urban development, this solution is recommended for one or two up-most floors.
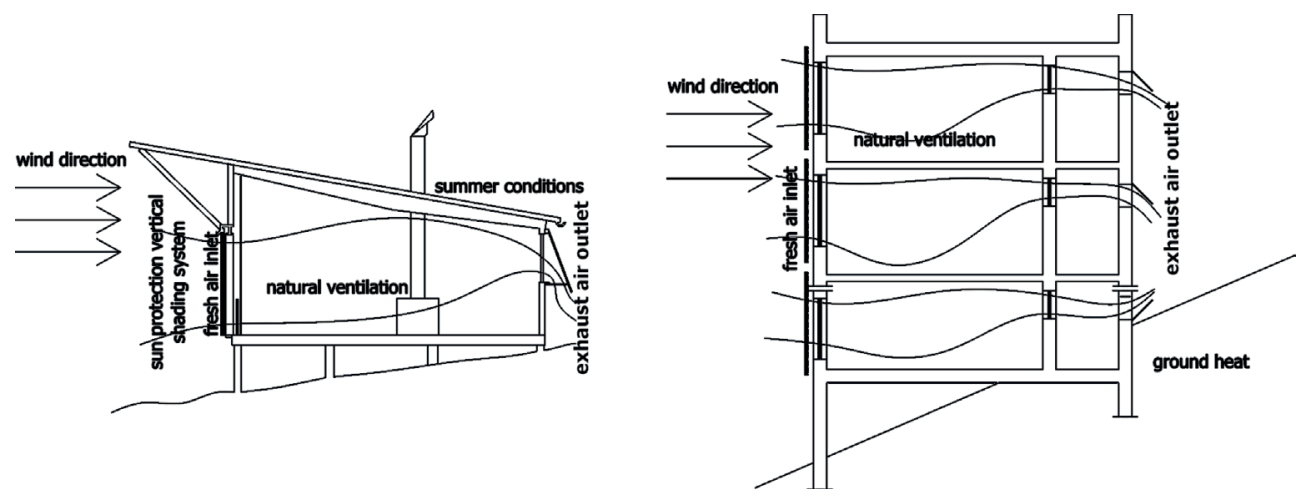

Figure 4: From left: Scheme of air movement in the 'Simpson-Lee House' designed by Glen Murcutt (illustration based on a drawing by craines [24]) and scheme of multi-storey hotel design composed of 'Murcutt units'. 


\subsection{Natural lighting and heating}

Natural lighting is used in ecological buildings not only to provide good conditions for work, wellbeing and hygiene but also as an element of heating in the so-called passive system. If the interior walls are exposed to direct sunlight, heat will accumulate in heavy building materials, such as concrete or brick, which will subsequently radiate into the air during the night. The optimal solution recommended by Zielonko-Jung and Marchwiński [5] for Polish locations is the one where the exterior walls facing south are at an angle of $60^{\circ}$ to the ground level, which helps to obtain maximum sunlight during the winter. They [5] also recall the research carried out by Klaus Daniels, which confirmed that the optimum passive heat gain in Poland can be achieved if the elements of a building that face south are slanted at an angle between +15 and $-15^{\circ}$. Apart from the orientation and location of the building, another important factor is its depth. Hotels are usually constructed in a corridor layout with rooms on both sides, which is the most economical solution as far as usable space and heating are concerned. Even if the longer exterior walls have the best possible exposure to easternsouthern sunlight, it is still impossible to take advantage of the 'solar-envelope' or direct the sunlight into the corridors of a multi-storey building. Because this solution did not prove effective, advanced technological systems were developed, such as photovoltaic cells (from smart materials) [5] and solar panels, which enable long-term accumulation of heat, heating of water and production of electricity.

\subsection{Natural heating}

In his projects, Glen Murcutt promotes a fireplace as an ecological source of heating, but due to high carbon dioxide emissions and maintenance difficulties such a solution is unacceptable for hotels. It would be much more effective to use a contemporary 'thermal-chimney' with water jacket, which could generate heat and transmit it via a central heating system to the entire building. On the other hand, there are many other much more effective systems, such as solar collectors, photovoltaic cells, wind turbines, geothermal heat pumps, biomass combustion systems powered by fluid, solid or gas fuels, and other economical and clean solutions, such as heat pumps based on water, air or ground heat, compressor, thermoelectric and condensing boilers [5].

According to Zielonko-Jung and Marchwiński [5], passive heating solutions could also benefit from additional climate zones inside a building. In the case of large-scale structures, they propose to create a hierarchy of interiors based on the following:

- the function and number of workers,

- the type of work,

- the time of the day or night when work is performed,

- the length of work,

- the type of a passive heating system used for each compartment (direct or non-direct, e.g. walls: Tromb's, water, LED, winter gardens, atriums).

Technical and service rooms, corridors and elevators, which require cooling may be placed close to the walls with minimum passive solar gain. In this manner, the natural sun envelope of a building can be used to the maximum. It is also important to properly insulate a building against temperature, water and interlayer condensation. The design of all the details must be well-thought to avoid thermal gaps while the doors and windows must meet certain standards. These issues are addressed in separate articles [3,26,27]. 


\subsection{Technological advancement and hybrid design}

On the opposite end of traditional natural solutions, there are eco-tech buildings with a technologically advanced and intelligent system. With its different solutions, such a building becomes an autonomous, zero-energy structure that may even generate electricity back to the grid. All the elements of such a structure must be controlled by a Building Management System (BMS), which controls the electronic equipment and optimizes energy use and production. Based on one or a few renewable energy sources, it could be supported by passive heating. Instead of conventional airconditioning, a central adiabatic air cooling system could be installed, which is based on water vapourization [5]. The costs of building such a hypothetical hotel are very high and it would be difficult to predict the income. Potential investors might be discouraged by the number of installations needed, their maintenance and service, and other problems connected with reliability and wear. Since these solutions are quite new and there are no examples of such structures working for 10 or 20 years, some designers might be reluctant to follow this trend. Instead of working with unpredictable technologies, it is becoming much more popular to use passive energy with renewable sources or to supplement economical heating with solar panels. However, so far these solutions can be considered as only partial and temporary measures on the road to full zero-energy and zero-emission buildings.

Excellent examples of hybrid designs can be found in the works of Ken Yeang, who first designs a building with the optimum number of passive energy and natural solutions and then supplements it with high-performance technological solutions. One such project is the 24-floor IBM Plaza skyscraper in Kuala Lumpur. Natural ventilation is used in the ground floor lobby and toilets, stairs and corridors on upper levels. Façades are cooled by a system of concrete blinds and carefully designed greenery [8]. A lot of openings allow plants to grow freely and let air into the structure to cool and ventilate the interior. An example of an even more advanced solution of this type is the National Library in Singapore. The interior street-like corridors of this large structure are naturally ventilated and illuminated by day light. Similarly, a vast plaza situated above 'vegetation cells', i.e. water collectors in vegetating containers, is ventilated by fresh air. The site for the library was chosen to obtain optimal natural lighting to maximize passive energy gain and create appropriate shading at the same time. Apart from these natural solutions, the building is equipped with air conditioning, which can be used on its own or in combination with natural ventilation. Sixty percentage of the building space is covered with greenery in the form of 'skycourts', which contain large trees and are 40-m tall so as to ensure proper tree growth [8]. The aforementioned designs by Ken Yeang constitute a good example of combining natural and technological solutions. Moreover, the architect experiments and incorporates different ecological trends in his architectural work.

\section{CONCLUSIONS}

What is positive about natural solutions in hotels is that they involve only slight interference into the structure of the building and that their implementation is simple and economical both in new and renovated buildings. Solutions based on the local climate, materials and culture fit into the regional context and bring people closer to nature and each other. The fact that these solutions do not emit pollution, gas, vibration or magnetic fields helps to preserve the surrounding ecosystem virtually untouched. In view of these arguments, it is very important to continue studies on possible natural eco-hotels and developing the aforementioned concepts. The implementation of sun-chimneys and wind towers into regional Polish architecture seems a viable possibility. Natural solutions should evolve to be better adjusted to our needs. On the other hand, eco-tech solutions are a quick remedy to many problems of the built environment and are also environmental friendly. Their advantage is 
the possibility to control each interior parameter, such as lighting, shading, air temperature and humidity, velocity of air flow, which provides comfort for each hotel guest individually in each hotel room. Nonetheless, eco-tech methods require a lot of specialized installations, they may create noise and vibration and even be harmful to local flora and fauna. They also require further development to become better and more innovative. The following table compares the possible systems for an ecological hotel (Fig. 5):

Some of the ideas mentioned above have already been implemented in hotels in Polish cities. 'Hotel Puro' in Wroclaw at Włodkowica Street uses a technologically advanced intelligent system - BMS, which is designed to limit the use of conventional energy. 'Hotel Ramka' in Poznań uses renewable energy sources, solar collectors and photovoltaic panels to generate energy, heating and warm water, and offers an electric vehicle charging station. 'Flower Hostel' in Wroclaw has implemented a recycling policy on a large scale. Similar trends are seen in hotels in rural Poland, such as 'HOT_elarnia' in Puszczykowo near the Wielkopolska National Park and 'Hotel Remes' in Opalenica which were built of natural materials. 'Dwór Oliwski' in Gdańsk, which is an example of architecture recycle concept, or 'Hotel Bukovina' in Bukowina Tatrzańska with its nearby large leisure centre, which use local resources, geothermal water sources, heat pumps and BMS [3].

It is impossible to list all of the best solutions for Polish hotels or to decide whether natural solutions are more suitable than eco-technological ones. This choice should be based on a thorough analysis of each individual hotel in terms of available resources, site, requirements of a given hotel and the possible use of renewable energy sources. Hybrid solutions usually offer the best results and keep the environment clean and healthy, while maintaining costs at the lowest possible level. It seems that a radical approach to any solution is a dead-end because the tendency to meet all possible ecological requirements is usually not sustainable. The literature and field studies provide many examples of how to coherently implement both of these opposite trends in ecological architecture.

\begin{tabular}{llll}
\hline Resource & Natural & Eco-tech & Function \\
\hline Sunlight & Passive heating & Solar panels & Heating \\
& & Photovoltaic cells & Generating electricity \\
\multirow{2}{*}{ Wind } & Sun chimneys & - & Cooling \\
& & Wind turbine & Generating electricity \\
Still air & Wind tower & - & Cooling \\
& - & Heat pump & Heating \\
& Cross ventilation & - & Cooling \\
Ground & Chimney ventilation & - & Cooling \\
& - & Heat pump & Heating \\
Still water & Ground channel & - & Cooling \\
& - & Heat pump & Heating \\
& Adiabatic process & Central air condition- & Cooling \\
& & ing based on adiabatic & \\
\multirow{2}{*}{ Water current } & - & process & \\
& Channel & Water turbine & Generating electricity \\
& & - & Cooling \\
\hline
\end{tabular}

Figure 5: Comparison of systems for an ecological hotel based on possible resources and usage. 
Based on aforementioned studies, the following extended definition of ecological hotel has been proposed: 'an ecological hotel is understood as a solution that is aimed at limiting its harmful influence on the natural environment and human health. It is designed to fit into its surroundings (urban or rural) through its architectural and technical features. The solutions implemented in order to achieve these goals can be both eco-technological and natural, depending on the location, available resources and the intended purposes of a given hotel'.

\section{REFERENCES}

[1] Kozak, B., Kształtowanie architektury proekologicznej. Rozwiązania proekologiczne a architektura budynku. Habitaty pro-eko-logiczne, ed. Z. Bać, Oficyna Wydawnicza Politechniki Wrocławskiej: Wrocław, pp. 128-132, 2010.

[2] Starowiejska, I. \& Fundacja Partnerstwo dla Srodowiska (eds), Czysta Turystyka czyli odpowiedź na potrzeby wspótczesnego turysty, Fundacja Partnerstwo dla Srodowiska: Kraków, 2011, p. 3.

[3] Trocka-Leszczyńska, E. \& Jablonska, J., Can a hotel be ecological? Eco-architecture IV. Harmonisation Between Architecture and Nature, ed. C.A. Brebbia, WIT Press: Southampton, Boston, pp. 115-125, 2012. doi: http://dx.doi.org/10.2495/arc120111

[4] Gwóźdź, E., Ekologia w architekturze i budynki zielone. Świat Architektury, 6(13), pp. 40-41, 56-57, 75-87, 68-69, 98-100, 2012.

[5] Zielonko-Jung, K. \& Marchwiński, J., Łaczenie zaawansowanych i tradycyjnych technologii $w$ architekturze proekologicznej, ed. O. Wydawnicza, Politechniki Warszawskiej: Warszawa, 2012, pp. 7, 40, 72-74.

[6] Trocka-Leszczyńska, E., Regional architecture - passive cooling systems. Passive cooling of buildings. International symposium. The Central Institution for Energy Efficiency Education (CIENE), Athens, Greece, pp. 295-302, 19-20 June 1999.

[7] Zaniewska, H. \& Barek, R., Proekologiczne budownictwo mieszkaniowe - filozofia czy rzeczywistość. Habitaty pro-eko-logiczne, ed. Z. Bać, Oficyna Wydawnicza Politechniki Wrocławskiej: Wrocław, 2010, pp. 23-29.

[8] Hart, S., EcoArchitecture: the Work of Ken Yeang, ed. D. Littlefield, John Wiley \& Sons, Ltd: Chichester, UK, pp. 22, 30, 46-49, 104-109, 2011.

[9] Massó, P. (ed.), Cool Hotels. Ecological, teNeues Publishing Group: Kempen, 2007.

[10] http://www.imgw.pl/wl/internet/zz/klimat/0701_bodzce.html (accessed 3 December 2012)

[11] Krause, M., Termoregulacja organizmu człowieka i obciążenie termiczne,Nauka o pracy bezpieczeństwo, higiena, ergonomia, CIOP, available at http://ergonomia.ioz.pwr.wroc.pl/ download/termoregulacja-teoria.pdf (accessed 03 December 2012), pp. 1-2.

[12] Pawlonka, A. \& Trocka-Leszczyńska, E., Economical aspects of thermal renovation of existing housing in Poland, CIB W70 Tokyo Symposium on Strategies and Technologies for Maintenance and Modernisation of Buildings, Vol. 2, Japan, pp. 971-978, 1994.

[13] Gaczoł, T., Wentylacja naturalna systemy nawiewu. Czasopismo Techniczne, 4-A, pp. 65-70, 2007.

[14] Rozporzqdzenie Ministra Infrastruktury w sprawie warunków technicznych, jakim powinny odpowiadać budynki i ich usytuowanie z dnia 12 kwietnia 2002 r (Official Journal No. 75, item $690)$, as amended.

[15] Huld, T., Pinedo-Pascua, I. \& CMS SAF, Map of Photovoltaic Solar Electricity Potential in European Countries, European Union 2012, available at http://re.jrc.ec.europa.eu/pvgis (accessed 30 December 2012). 
126 E. Trocka-Leszczyńska \& J. Jablonska, Int. J. of Design \& Nature and Ecodynamics. Vol. 10, No. 2 (2015)

[16] Kirby, M., History and Use of Windcatchers in Traditional Middle Eastern Architecture, 2011, available at http://voices.yahoo.com/history-windcatchers-traditional-middle-8374397.html (accessed 22 November 2012).

[17] A'zami, A., Badgir in traditional Iranian architecture, International Conference on "Passive and Low Energy Cooling 1021 for the Built Environment", May 2005, Santorini, Greece, pp. 1021-1026, available at http://www.inive.org/members_area/medias/pdf/ Inive\%5Cpalenc\%5C2005\%5CAzami2.pdf (accessed 27 December 2012).

[18] Elgendy, K., A Damascus school revives traditional cooling techniques, Carboun. Middle East Sustainable Cities, available at http://goumbook.com/a-damascus-school-revives-traditionalcooling-techniques/ (accessed 19 October 2012).

[19] http://archrecord.construction.com/features/aiaawards/09goldmedal/1.asp (accessed 19 October 2012).

[20] Becker, L., Force of nature, “Repeat” 2004-2006, available at http://www.lynnbecker.com/ repeat/murcutt/murcutt.htm (accessed 19 October 2012).

[21] http://www.architecture.com.au/emailnews/national/Heritage/NSW-Simpson-Lee-House-II. pdf (accessed 19 October 2012).

[22] Craven, J., The Magney House by Glenn Murcutt, About.com, available at http://architecture. about.com/od/houses/ss/magneyhouse.htm (available at 19 October 2012).

[23] Craven, J., The Marika-Alderton House by Glenn Murcutt, About.com, available at http://architecture.about.com/od/houses/ss/marikaalderton.htm (accessed 19 October 2012).

[24] http://wiki.naturalfrequency.com/wiki/Air_Movement (accessed 19 October 2012).

[25] Jabłońska, J., Łatak, K. \& Lewicki, P., CorteVerona. Wywiad z Kazimierzem Łatakiem i Piotrem Lewickim z Biura Projektów Lewicki Łatak z Krakowa. Świat architektury, 3, pp. 44-48, 2010.

[26] Pawlonka, A. \& Trocka-Leszczyńska, E., New structural solutions for outside walls in the aspect of energy-saving and improvement of thermal comfort in flats, Proceedings of the 3rd International Conference on Healthy buildings '94, Technical University of Budapest, Budapest, Hungary, 1994, pp. 375-380.

[27] Trocka-Leszczyńska, E., Modernization of existing buildings reduction of heat loss and energy consumption. Acta Academiae Polytechnicae "Pollack Mihaly"< Pecs", 1990, pp. 200-203. 